maximum widths of the relaxation spectra are com. pared with those relating to the viseo-elastic effects of the entire network. The distribution of relaxation periods suggests a distribution of the activation energies governing the process. A measure is thereby obtained of the associated distribution of potential barrier heights in the vitreous network. The migration of a network-modifying ion is subject to a wider range of irregularity of activation energy than the general visco-elastic deformation of the network-forming ions.

Drs. A. W. Pryor and E. G. Richardson (Physics Department, Newcastle) have carried out experiments using ferrite transducers of 50 and 100 kc./s. excited magnetostrictively to send torsional waves down long rods made of metal or glass. By varying the temperature in a container surrounding the rod, and measuring the attenuation and phaseshift of transmitted pulses, the elastic modulus and viscosity of the material of the rod or of a liquid under shear in the container were measured. The absorption is less in solutions of rubber in benzene than in pure solvent. The fact that the absorption in these highly viscous solutions is many times less than those calculated from the classical formula-by substituting the known shear viscosities-can be explained by assuming that the high viscositios are by-passed by associated elasticities (that is, these liquids behave at high frequencies more or less as solids).

\section{ADOPTION OF THE UNIFIED SCREW THREAD BY BRITISH INDUSTRY}

$\mathrm{R}$ EPRESENTATIVES of many branches of the engineering industries, the Service Departments and the nationalized industries met recently at the British Standards Institution, under the chairmanship of Mr. H. A. R. Binney, director of the Institution, to review how far the Unified Screw Thread has, in fact, been adopted in Great Britain. The conference was called in response to many inquiries as to how far and how fast the change-over from the Whitworth Thread has progressed during the seven years since the signing of the "Declaration of Accord" between the United States, Britain and Canada, under which the three countries agreed to accept the Unified Thread.

During the years immediately following the signing of the Accord, several British Standards were developed by the Institution for Unified bolts and nuts, screwing tackle and other details necessary for the implementation of the agreement. In the early stages manufacturers of bolts and nuts were unable to meet all the demands for Unified bolts and nuts; but recently the position has improved. The draft standard for black bolts and nuts in the 'normal' series will soon be issued, and manufacturers now foresee no serious difficulty in meeting any future demands likely to be made upon them. The motor, aircraft, oil and chemical industries and the Atomic Energy Authority have all adopted the Unified Screw Thread, and have found that the change-over has not been nearly as inconvenient as they had thought it would be. One of the major difficulties to be faced is not so much the change from Whitworth to Unified bolts and nuts; but the fact that tapped holes are employed in such a great variety of engineering equipment and that this equipment is produced in a wide range of separate industries which includes many eomparatively small firms. The opinion at the conference was that the three key groups which can do most to further progress of the change-over are large organizations, such as the nationalized industries, with their ability to influence the market by the many large orders for equipment which they place; the stockist, who is responsible for supplying small orders to a great number of small firms; and the many small manufacturers, who produce miscellaneous industrial equipment with tapped holes.

Although the rate of the change-over to the new thread has been considerably faster than might have been expected some four or five years ago, the advantages to be achieved by working to a single screw-thread system, particularly one which there is every reason to believe will receive increasing support in the Commonwealth and other overseas markets, are so great as to make it very desirable that the tempo of the change-over should be increased. The British Standards Institution was asked to take such steps as may be appropriate to secure wider publicity for this objective, and it was decided that the conference should meet again in about six months time to review the progress then made.

\section{SUBJECT SPECIALIZATION AND CO-OPERATIVE BOOK PURCHASE IN BRITISH LIBRARIES}

N Library Association Pamphlet No. 12 (pp. 32 ; 1955), Mr. K. G. Hunt, chief librarian of Hammersmith Public Libraries, contributes a useful survey of schemes in subject specialization and co-operative book purchase by libraries in Great Britain, concluding with a quotation from the second interim report (January 1954) of the Working Party of the Library Association. Mr. Hunt gives first some examples of comprehensive schemes arranged by the universities and special libraries. In London, for example, while each of the specialist hospitals covers its own subject, the University Library is building up a large collection of medical periodicals. At Oxford the book selection committee of the Science Library, on which the departmental libraries are represented, avoids a duplication of expensive specialized scientific works. Most of the examples given by Mr. Hunt are outside the field of science, but for medicine the London School of Hygiene, the Medical Research Council, the Royal College of Physicians, the Royal College of Surgeons, the Royal College of Veterinary Surgeons, the Pharmaceutical Society and the Medical Science Library of University College formed a co-operative group, to which the British Medical Association also is attached; this group attempts to arrange that each library keeps to certain fields and informs the others of changes of holdings of periodicals.

A fairly full account of the Metropolitan Special Libraries scheme, inaugurated in 1948 by London Metropolitan public libraries, follows next in the pamphlet. This scheme enabled its constituent libraries to give a service far in excess of what was previously available and has also contributed towards a solution of the storage problem. Later, in January 1950, the South-Eastern Regional Library Bureau's 
scheme came into existence, under which an attempt was made to ensure that all newly published books were bought somewhere in the area. Afterwards, responsibilities under the scheme were assigned according to the resources of each library, and each library was also asked to become responsible for the biographies of persons connected with their special subjects. Later still, schemes were started among the public libraries of the Northern Region, the East Midlands (limited to books in foreign languages), Wales (for certain specialized books), and in April 1954, in the North-Western Region (in which seventy-five libraries participated, but periodicals and purchase of older books are excluded).

Mr. Hunt suggests that the most necessary future developments are likely to be concerned with increasing the provision of foreign books, and co. ordinating and improving the supply of periodicals. Such problems are mainly the concern of university and special libraries; but the various regional schemes of public library co-operation could easily be coordinated and improved by dividing the responsibilities for still higher degrees of specialization between the specializing libraries in each subject in each region on a systematic and orderly basis. This would give strong support to any co-ordination attempted by research institutions acting alone.

\section{AMERICAN PHILOSOPHICAL SOCIETY}

\section{YEAR BOOK FOR 1954}

$T$ HE Year Book for 1954 of the American Philosophical Society* includes E. G. Conklin's brief history of the Society, its charter aud laws, reports of standing committees, and the usual lists of members and biographical memoirs, among which may be noted those of M. T. Bogert, Sir Henry Clay, K. T. Compton, H. E. Ives, T. Lyman, R. A. Millikan and H. A. Spoehr. The report of the Committee on Research lists 165 grants, totalling 144,770 dollars, and one conditional grant of 600 dollars, made during the year from the Penrose Fund. Six of these, totalling 8,300 dollars, were in astronomy, physics and chemistry; thirty-six, totalling 29,195 dollars, in zoology, botany, anthropology, biochemistry, physiology, psythology and related sciences; forty, totalling 37,755 dollars, in history, political science, economics and sociology; and eighty-three, totalling 72,520 dollars, in ancient, medieval and literary history, archæology, philology, art, literature, etc. Eight grants, totalling 21,336 dollars, were made from the Johnson Fund and six grants, totalling 13,335 dollars, from the Daland Fund for Research in Physical Medicine.

Reports from recipients of grants occupy some two hundred and fifty pages of the report of the Committee on Research. Among the more detailed of these summaries may be noted those of $\mathrm{H}$. B. Levi on recent progress in the field of radiocarbon dating; M. K. Hecht on the comparison of recent and fossil amphibian, reptilian and mammalian faunas in the Bahamas; A. Carr's survey of the zoogeography and migrations of sea turtles, which indicates that under present conditions the green turtle is likely to be extirpated from the Caribbean

* American Philosophical Society. Year Book, 1954. Pp. 605. (Philadelphia : American Philosophical Society, 1955.) within twenty years although it appears to be peculiarly amenable to conservation; K. T. Guthe's study of the myosin adenosine triphosphate of the echinoderm Stichopus; and C. J. Heusser's studies of glacier fluctuation, forest succession and climatic variation in the Canadian Rockies and pollen profiles from the Queen Charlotte Islands, northern Vancouver Island and northern coastal British Columbia. R. Singer reports on studies of the Basidiomycetes of South America in European herbaria, and J. L. Angel on the evidence as to human biology, health and history in Greece obtained by careful study of human bones excavated in Greece; M. J. Herskovitis reports on field work in sub-Saharan Africa to assess how pre-existing cultural patterns react to different rates of industrialization and technological innovation, within the limits of differing Colonial policies, while W. B. Schwab discusses the analysis of material collected in a socio-economic survey of the Yeruba community in Nigeria with the object of examining the interrelations of urbanization and acculturation.

D. R. Brown summarizes an investigation of the effects on cortical currents of organic damage to the brain by the use of a behavioural measure involving the kinesthetic figural after-effect which appears to support the assumption that the lesion introduced in a lobotomy sets up a temporary physiological disturbance in the cortex which will change the conductivity of the higher brain centres and therefore the kinesthetic after-effect. W. S. Verplanck describes an interchange of experimental techniques and theoretical structures between European ethologists and American psychologists; and L. S. Ciereszko gives an account of the determination of vanadium in tunicates and of acidity in Ascida nigra as well as the collection, identification and preparation of various tunicates, sponges and gorgonians. N. C. Li reports on metal complexes of peptides containing sulphur, H. W. Neuberg on the metabolism of phosphophenolpyruvate, F. W. Crane on the spores of Dryopteris, and G. T. Johnson on the Mississippi species of the Trypetheliaceae.

In the social sciences, D. W. Meinig describes and analyses the nature of man's contact with the major agricultural frontier of the Pacific north-west and the Columbia Plateau grain region from 1805 to about 1910 , and C. T. Mason an inquiry into the non-profit research institute and how it functions. In archæology, H. A. Carey reports on a study of the ancient Indian culture centring in the Casas Grandes Valley, north-west Chihuahua, Mexico; F. E. Day on early Islamic pottery related to that of Tarsus and 'Arija Hafir'; K. P. Kent on the textile industry of prehistoric south-western Pueblo peoples, particularly with regard to weaving in cotton; R. S. MacNeish on the development of agriculture and the concomitant development of civilization in MesoAmerica, Tamaulipas, Mexico ; H. C. Palmatary on Brazilian, Swedish and American Tapago pottery; and A. N. Stilwell on pottery from the Potters' Quarter in Corinth. P. Drucker describes a study of intertribal organizations of the north-west coast of the United States, I. Greenwald a study of the history of goitre, and C. Eisele one of C. S. Peirce and the history of science. Investigations of the freshwater ostracods of South Carolina are described by E. Ferguson, taxonomic and ecologic researches on the ants of Nevada by A. G. Cole, and a detailed field study of spring Orthoptera in western and southwestern States by J. A. G. Rehn. 